\title{
Use of Bioelution as a Screening Tool for Characterisation of Substances
}

\section{Noömi Lombaert ${ }^{* \#}$, Carol Mackie ${ }^{2 \#}$, Violaine Verougstraete ${ }^{3}$, Tony Brouwers ${ }^{4}$, Frank Van Assche', Adriana Oller ${ }^{5}$}

\author{
${ }^{1}$ International Zinc Association, Reach Indium Consortium, Brussels, Belgium \\ ${ }^{2}$ Regulatory Compliance Ltd., Loanhead, UK \\ ${ }^{3}$ Eurometaux, Brussels, Belgium \\ ${ }^{4}$ ECTX Bvba, Hasselt, Belgium \\ ${ }^{5}$ NiPERA Inc., Durham, USA \\ Email: *nlombaert@zinc.org
}

How to cite this paper: Lombaert, N., Mackie, C., Verougstraete, V., Brouwers, T., Van Assche, F. and Oller, A. (2018) Use of Bioelution as a Screening Tool for Characterisation of Substances. American Journal of Analytical Chemistry, 9, 134-149. https://doi.org/10.4236/ajac.2018.93012

Received: January 30, 2018

Accepted: March 10, 2018

Published: March 13, 2018

Copyright (C) 2018 by authors and Scientific Research Publishing Inc. This work is licensed under the Creative Commons Attribution International License (CC BY 4.0).

http://creativecommons.org/licenses/by/4.0/

\section{Open Access}

\begin{abstract}
Bioelution, the measuring of in vitro metal ion release from metals or metal compounds in simulated body fluids, can be used as a tool to measure bioaccessibility of metals and metal compounds, and as such provide an estimate of their bioavailability. Comparable bioelution results can allow grouping of substances within a "metal" family. By referring to toxicity data on a metal substance (reference substance) within the group, predictions on the hazard of the other substances in the group can be established. This paper discusses how bioelution testing of metals and metal compounds can be used as an alternative to animal testing for obtaining basic information on their potential toxicity, while allowing compliance with strict information requirements. Two human health hazard endpoints are used to illustrate how bioelution can become part of a testing programme and in particular, target the requirement for new studies and minimise the need for animal testing. In these cases, it is shown how bioelution can be used to predict the hazard of several indium compounds as a first screening.
\end{abstract}

\section{Keywords}

Metals, Grouping, Bioelution, Information Requirements, Read-Across

\section{Introduction}

The metal industry has a great interest in minimising the use of animal tests in regulatory compliance and in supporting the use of alternative in vitro methods

\#Both authors contributed equally to this work. 
for testing the safety of materials. Furthermore, many regulations (e.g. EU $\mathrm{REACH}$ ) also request that testing programmes should be conducted minimising animal testing where appropriate. There is currently extensive research ongoing to develop suitable in vitro methods.

These in vitro methods embrace the Three R's concept (Replace, Reduce and Refine), proposed by Russell and Burchin "The Principles of Humane Experimental Technique" [1], who launched a programme for the humane treatment of laboratory animals in experimental biology. Based on the Three R's, laws of many countries and Directive 86/609/EEC of the European Union that now specifically require replacement-reduction-and refinement alternatives should be used wherever and whenever possible in biomedical research, testing and education.

To place substances on the market, EU REACH requires a number of information requirements on toxicity to be fulfilled. The toxicity of most metal substances and complex materials containing metals is related to the bioavailability of metal ions.

Bioavailability is in general defined as the extent to which a substance is taken up by an organism and is available for metabolism and interaction. The bioavailability of most metal substances is defined as the extent to which the soluble metal ion can be released, taken up in the body and made available at the target organ/site.

Several factors may affect bioavailability and consequently, the amount of ions that will be able to interact at a target site (e.g. their solubility, physical form, inclusion into a matrix or complex structure as in alloys, pigments, glasses, etc.).

Information on bioavailability is usually obtained from toxicokinetic studies for all relevant routes of exposure and all relevant forms or physical states where the substance and/or metabolite(s) of the substance have been quantified in body fluids and/or target organs. In situations where the bioavailability of a substance/material is not known or where it is not feasible to determine this in vivo, bioaccessibility may be used to estimate bioavailability. Bioaccessibility is defined as the fraction of a substance that dissolves under surrogate physiological conditions and, therefore, is "potentially available" for absorption into systemic circulation. Bioelution refers to the in vitro extraction methods used to measure the degree to which a substance (e.g. metal ion) is released in artificial biological fluids. Bioelution tests are thus used to estimate a substance's bioaccessibility (usually in the form of metal ions), i.e. its solubility under physiological conditions.

Considering that it is not acceptable, from an animal welfare viewpoint, to perform in vivo studies for each specific material and each endpoint, insight into processes determining and quantifying bioavailability is required to be able to predict toxicity in a weight-of-evidence approach. In this context, bioelution testing-to estimate bioavailability-has become an active research area with both individual researchers and research groups working to develop and validate 
bioelution protocols.

The use of bioelution tests is an excellent example of a reliable alternative method for animal testing that allows compliance with strict information requirements in chemicals management while minimising animal testing. This approach has been applied to human exposures to metals and minerals in soils, consumer products and in the evaluation of metal substances [2]-[23].

The main advantages of bioelution tests to predict bioavailability can be summarized as follows:

- Reduction in animal testing.

- Results from bioelution tests are reproducible.

- Bioelution tests are considered as conservative as they estimate the potential bioavailability of the test substance (bioaccessibility), before absorption takes place.

- Bioelution tests are inexpensive, rapid and reproducible.

- Bioelution tests can be tailored to provide data for specific exposure pathways. e.g.

o Dermal exposure: the dissolution in artificial sweat can be used to estimate the metal ion bioaccessibility in the surface layer in contact with the skin to support predictions for both sensitisation potential (e.g. BS EN 1811 for nickel [24]) and systemic effects following dermal uptake.

o Oral route: the dissolution in various artificial saliva/gastric/intestinal fluids can be used to estimate the relative metal ion bioaccessibility to support predictions of systemic effects following oral exposure.

o Inhalation route: bioelution tests may give a first estimate of the "persistence"/dissolution of the substance at the lung level, however for this particular route, given its complexity, a more mechanistic approach should be applied. Data from dissolution in simulated lung/lysosomal fluids should be complemented by information on inhalability and particle deposition to be able to predict systemic inhalation effects. For local effects, factors other than the concentration of the ion at the target site may be important in determining toxicity in the lung (e.g. particle effect, lung overload, redox reactions, oxidative stress, and change in $\mathrm{pH}$ ). Bioelution results should therefore not be used in isolation to predict toxicity.

The potential applications of bioelution testing for metals and metal-containing materials are: grouping and read-across of substances and mixtures for hazard identification (i.e. fulfil data requirements), classification or for prioritisation of in vivo testing.

This paper provides insights on bioelution studies applied to metalsubstances to fulfil toxicological information requirements in chemicals management schemes like EU REACH. Bioelution results should always be used in a conservative, weight-of-evidence approach as there are limitations to the test and its applicability. In order to be acceptable to regulatory authorities and to give confidence to the user of the metal, metal substance and complex metal containing 
material, it is imperative that all regulatory submissions and applications contain high quality, reproducible data and that the scope/limitations are well defined.

\subsection{Availability and Status of Bioelution Methods}

Bioelution is not a "new" concept and in some regulatory areas it is already wellestablished in assessing the bioavailability of metals in environmental matrices and articles. For example, in vitro bioaccessibility has been used by the US Environmental Protection Agency, US EPA to predict relative bioavailability of lead from soil for gastrointestinal absorption [25].

The following bioelution methods have been formalised in EU and elsewhere as standards for product testing:

BS EN 71.3 [26] and ASTM F-963 [27]: Methods for determining toy safety which specifies requirements for the migration of metals from toy materials

BS EN 1811 [24]: Nickel release from consumer articles intended for prolonged and direct skin contact

ASTM D-5517 [28]: Extractability of metals from art materials

BARGE [29]: The Bioaccessibility Research Group of Europe (BARGE) studies human bioaccessibility of priority contaminants in soils such as arsenic, lead and cadmium via the gastrointestinal tract

Guidance on how to conduct specific bioelution tests is also available from several regulatory authorities (e.g., [25] [30]). However, to date there are no established OECD or EU bioelution test protocols relevant to the oral, inhalation and/or dermal routes of exposure that are applicable for metal substances.

\subsection{Main Considerations in Developing Bioelution Methods}

It is recognised that clarity and reproducibility of the methodology are key aspects to allow the application of bioelution testing. The development of reproducible tests, utilising internationally accepted protocols is crucial in the following aspects:

- The choice and composition of artificial fluids should be representative of the route of exposure to a metal substance/matrix.

- Research has demonstrated that there are several parameters in the bioelution settings that can have asignificant influence on the dissolution kinetics of the tested materials. Examples of such parameters are: composition, ionic strength and $\mathrm{pH}$ of the extraction fluid, temperature, light conditions (e.g. darkness), fluid agitation rate, duration of the extraction process, loading and particle size/surface area of the tested substance.

- Those parameters should be carefully considered in the design of the bioelution methods to ensure reproducibility and reliability, but also their influence on the interpretation of results should be taken into account.

- The treatment of the test material before the testing can affect the results of bioelution testing e.g. milling a metal prior to testing may change the matrix properties of the test material and could result in spurious results. It is there- 
fore important that, as far as possible and feasible, the substance is tested as it is expected to be available under the foreseeable conditions of use.

- Release results can be expressed regarding either the bioaccessibility of the metal in e.g. mg metal ion/litre, mg metal ion/g sample, mg metal ion/g metal in the sample or as a release rate (e.g. mg metal ion/litre/hour) or corrected by surface area when relevant.

In this manuscript, we present two examples of how bioelution results were used to predict acute toxicity and sensitisation effects of indium metal and indium compounds following oral and dermal exposure, respectively. The Indium REACH consortium is preparing the 2018 REACH Registration files for a defined number of indium compounds, i.e. indium metal and a number of inorganic indium III compounds $\left(\mathrm{InCl}_{3}, \operatorname{In}\left(\mathrm{NO}_{3}\right)_{3}, \operatorname{In}(\mathrm{OH})_{3}, \operatorname{In}_{2} \mathrm{O}_{3}, \operatorname{In}_{2} \mathrm{~S}_{3}\right)$. The consortium has screened the available hazard data on these compounds to identify possible data gaps when fulfilling the information requirements. It appeared that toxicological information on indium metal and indium compounds is very scarce, namely on acute oral toxicity and skin sensitisation. However, in analogy with the toxicity of other inorganic metal compounds, it can, be assumed that the toxicity of the indium substances for these endpoints is related to the bioavailability of the indium ion, i.e. its release from the indium substances and resulting solubilisation under physiological conditions. Bioelution testing based on the ASTM D 5517-07 [28] and BS EN 1811 [24] was therefore carried out. The releases of the indium metal ions were measured and compared to the available toxicity data on these indium compounds, to be able to

1) Group indium substances with similar bioelution pattern in given synthetic biological fluids

2) Define, based on these groups, which substance(s) to test in vivo for specific endpoints where relevant

3) Perform animal testing for the specific endpoints on the substance identified under $b$.

4) Read-across toxicities within and/or between the groups identified under a.

The outcome of this exercise is reported here together with a discussion of the applicability and limitations of the approach.

\section{Materials and Methods}

\subsection{General Study Design}

The bioelution testing was performed at ECTX-Consult, Belgium. Analysis of the concentrations of dissolved indium was performed at Water laboratorium Noord (WLN) (The Netherlands).

This testing was conducted according to the recommended Standard Operating Procedure (SOP) for the Bioaccessibility Testing Programme of Eurometaux [31] which is based on ASTM D5517-07 [28]: standard test method for determining the extractability of metals from art materials.

Bioelution was conducted in two synthetic biological fluids: gastric and sweat. 
The test fluids were added to the test items and extracted for a set period of time under standard conditions (e.g. $\mathrm{pH}$, temperature). Following a filtration step, extracts were analysed, and the amounts of indium released into solution were reported. Extractions in gastric fluid were conducted for $2 \mathrm{~h}$ based on an average time for gastric emptying of 17.7 minutes and complete emptying of 91 minutes in human volunteers [32]. Extractions in synthetic sweat were carried out for 24 h, $72 \mathrm{~h}, 120 \mathrm{~h}$ and $168 \mathrm{~h}$ to cover relevant exposure times on the skin [4].

\subsection{Test Materials}

The sixtested materials are the ones in the scope of the indium consortium and are listed in Table 1 with their respective CAS number, chemical formula, purity or concentration of indium, particle size, and physical form. All samples were provided by the REACH consortium members and represented the form and particle size as placed on the market and under foreseeable conditions of use.

\subsection{Laboratory Equipment}

All chemicals used to prepare the test fluids were of analytical grade reagent quality or better unless otherwise stated. Test vessels were new, pre-cleaned and acid-rinsed closed borosilicate 3.3 Erlenmeyer flasks (250 ml with GL45 screw cap). A temperature controlled orbital laboratory shaker (171 rpm, stroke length: $2.54 \mathrm{~cm}$ ) was used for agitation. For temperature and $\mathrm{pH}$ measurement, an HACH HQ40d multimeter was utilised. For filtration, $0.2 \mu$ m Pall Acrodisc ${ }^{\oplus} 25$ $\mathrm{mm}$ syringe filters, and $0.1 \mu \mathrm{m}$ Pall Acrodisc ${ }^{\oplus} 25 \mathrm{~mm}$ syringe filters were used. Latex- and oil-free syringes were used for sampling. Polypropylene sample tubes were used.

Table 1. Description of test substances used in this study.

\begin{tabular}{|c|c|c|c|c|c|c|}
\hline Test Item & Batch & CAS No. & Formula & $\begin{array}{c}\text { Purity Test Material } \\
\text { (\% Indium) or Conc. Indium }(\mathrm{g} / \mathrm{L})\end{array}$ & Particle size & Physical form \\
\hline $\begin{array}{l}\text { Indium(III) } \\
\text { chloride }\end{array}$ & UP566 & $54097-72-2$ & $\mathrm{InCl}_{3}$ & $\begin{array}{l}\text { Conc: } 169 \mathrm{~g} / \mathrm{L} \mathrm{In} \\
\text { Density: } 1.25 \mathrm{~kg} / \mathrm{L} \\
(13.52 \% \mathrm{w} / \mathrm{w} \mathrm{In})\end{array}$ & N/A & Solution $^{\mathrm{a}}$ \\
\hline $\begin{array}{l}\text { Indium(III) } \\
\text { nitrate }\end{array}$ & IN202 & $13770-61-1$ & $\operatorname{In}\left(\mathrm{NO}_{3}\right)_{3}$ & $\begin{array}{c}\text { Conc: } 89.8 \mathrm{~g} / \mathrm{L} \text { In } \\
\text { Density: } 1.214 \mathrm{~kg} / \mathrm{L} \\
\quad(7.4 \% \mathrm{w} / \mathrm{w} \mathrm{In})\end{array}$ & $\mathrm{N} / \mathrm{A}$ & Solution $^{\mathrm{a}}$ \\
\hline Indium metal & F10164 & 7440-74-6 & In & Purity: $99.99 \%$ In & $\begin{array}{l}99 \%<100 \mu \mathrm{m} \text { after } \\
\text { milling and sieving }\end{array}$ & $\begin{array}{c}\text { Solid } \\
\text { (powder) }\end{array}$ \\
\hline $\begin{array}{l}\text { Indium(III) } \\
\text { hydroxide }\end{array}$ & OH-1306 & 20661-21-6 & $\operatorname{In}(\mathrm{OH})_{3}$ & (72.9\% In) & $90 \%$ is $<20.4 \mu \mathrm{m}$ & $\begin{array}{c}\text { Solid } \\
\text { (powder) }\end{array}$ \\
\hline Indium(III) oxide & OX-2857 & $1312-43-2$ & $\mathrm{In}_{2} \mathrm{O}_{3}$ & $\begin{array}{l}\text { Purity: } 99.996 \% \\
(82.71 \% \text { In })\end{array}$ & $\begin{array}{c}\mathrm{d} 90<8.62 \mu \mathrm{m} ; \mathrm{d} 50< \\
4.23 \mu \mathrm{m} ; \mathrm{d} 10<1.43 \mu \mathrm{m}\end{array}$ & $\begin{array}{c}\text { Solid } \\
\text { (powder) }\end{array}$ \\
\hline $\begin{array}{l}\text { Indium(III) } \\
\text { sulfide }\end{array}$ & $\mathrm{In}_{2} \mathrm{~S}_{3}-2010-5$ & $12030-24-9$ & $\mathrm{In}_{2} \mathrm{~S}_{3}$ & $\begin{array}{c}\text { Purity: } 99.99 \% \\
(70.47 \% \text { In })\end{array}$ & $>99 \%$ is $<100 \mu \mathrm{m}$ & Solid (powder) \\
\hline
\end{tabular}

N/A, not applicable. Note a: used as a positive control to ensure that there was $100 \%$ recovery of the indium solution. Bioelution tests in principle are used for determining the release of metal ion from sparingly soluble forms of the metals. 


\subsection{Bioaccessibility Assays}

\subsubsection{Preparation of Simulated Fluids}

The compositions and general testing conditions of each of the simulated fluids, including $\mathrm{pH}$, temperature, loading, and extraction duration, are described in Table 2 .

\subsubsection{Setup for 2 Hours Bio-Elution Test on Test Item at a $200 \mathrm{mg} / \mathrm{L}$ Loading in a Simulated Gastric Fluid}

One borosilicate Erlenmeyer flask of $250 \mathrm{~mL}$ was used for the blank control. In the test vessels, $10 \mathrm{mg}$ of test item was weighed in triplicate into three separate $250 \mathrm{~mL}$ Erlenmeyer flasks. $50 \mathrm{~mL}$ of extraction fluid $\left(37^{\circ} \mathrm{C} \pm 1^{\circ} \mathrm{C}\right)$ was added to each test item vessel and blank control vessel. After swirling the flasks to mix the test item and the medium, the $\mathrm{pH}$ of the solution of test vessel replicate1 was checked to assure that it is at $1.5 \pm 0.1$. Since the $\mathrm{pH}$ did not alter after addition of the test system to the test item, there was no need for $\mathrm{pH}$ correction in the test vessels. The flasks were covered with a screw cap and placed into a temperature

Table 2. General description of bioelution fluids and protocols.

\begin{tabular}{|c|c|c|c|c|}
\hline \multirow[b]{2}{*}{ Composition of fluid } & \multicolumn{2}{|l|}{ Gastric } & \multicolumn{2}{|l|}{ Perspiration } \\
\hline & Reagent & $\mathrm{mL} / \mathrm{L}$ & Reagent & $g / L$ \\
\hline \multicolumn{5}{|c|}{ Sodium chloride } \\
\hline & \multirow{3}{*}{ Hydrochloric acid (30\%) } & & Urea & \\
\hline & & & Lactic acid $(90 \%)$ & \\
\hline & & & $\begin{array}{c}\text { Concentrated ammonia until a } \\
\text { stable } \mathrm{pH} \text { of } 6.5 \pm 0.1 \text { was reached. }\end{array}$ & \\
\hline $\mathrm{pH}$ & $1.5 \pm 0.1$ & & $6.5 \pm 0.1$ & \\
\hline Temp $\left({ }^{\circ} \mathrm{C}\right)$ & $37 \pm 1$ & & $30 \pm 1$ & \\
\hline Loading (g/L) & 0.2 & & 2 & \\
\hline Time (hours) & 2 & & $24,72,120$ and $168^{*}$ & \\
\hline Protocol overview & $\begin{array}{l}\text { One borosilicate Erlenmeyer flask of } 250 \mathrm{ml} \text { was used } \\
\text { for the blank control. In the test vessels, } 10 \mathrm{mg} \text { of test } \\
\text { item was weighed in triplicate into three separate } 250 \\
\mathrm{ml} \text { Erlenmeyer flasks. } 50 \mathrm{~mL} \text { of extraction fluid was } \\
\text { added to each test item and blank control vessel. After } \\
\text { swirling the flasks to mix the test item and the } \\
\text { medium, and adjusting the pH, the flasks were } \\
\text { covered with a screw cap and placed in a temperature } \\
\text { controlled orbital shaker at an agitation rate of } 171 \\
\text { rpm (revolutions per minute) for one hour. } \\
\text { Flasks were allowed to sit without agitation } \\
\text { for one additional hour before } \\
\text { sampling. }\end{array}$ & 7.41 & $\begin{array}{l}\text { One hundred mg of test item was weighed into } \\
\text { twelve separate } 250 \mathrm{~mL} \text { Erlenmeyer flasks, three } \\
\text { replicate flasks for each sampling time } \\
\text { (i.e. at } 24,72,120 \text { and } 168 \text { hours). } 50 \mathrm{~mL} \text { of extraction } \\
\text { fluid was added to each test item and blank control } \\
\text { vessel. After swirling the flasks to mix the test item } \\
\text { and the medium, and adjusting for pH, the flasks } \\
\text { were covered with a screw cap and placed in a } \\
\text { temperature controlled orbital shaker without } \\
\text { agitation for } 24,72,120 \text { and } 168 \text { hours. }\end{array}$ & $\begin{array}{c}1.0 \\
1.06\end{array}$ \\
\hline
\end{tabular}

A syringe was used to remove a $15 \mathrm{ml}$ sample from each test vessel at a depth of two third of the supernatant.

The samples were filtered through a $0.1 \mu \mathrm{m}$ or $0.2 \mu \mathrm{m}$ syringe filter ${ }^{\star *}$ and transferred to tubes for storage of less than one month.

*72 and $120 \mathrm{~h}$ added to study design to determine kinetics, however results showed low solubility over the time of exposure ${ }^{\star *}$ no significant differences in dissolved indium concentrations could be noted between the $0.2 \mu \mathrm{m}$ filtered samples and the $0.1 \mu \mathrm{m}$ filtered samples. Therefore, all further calculations and reported data, as below, were performed using the $0.2 \mu \mathrm{m}$ filtered data only. 
controlled orbital shaker $\left(37^{\circ} \mathrm{C} \pm 1^{\circ} \mathrm{C}\right)$ at an agitation rate of $171 \mathrm{rpm}$ (revolutions per minute) for one hour. After that, the flasks were settled at $37^{\circ} \mathrm{C} \pm 1^{\circ} \mathrm{C}$ for another hour.

\subsubsection{Setup for 168 Hours Bio-Elution Test on Test Item at a $2 \mathrm{~g} / \mathrm{L}$ Loading in a Simulated Perspiration Fluid}

Four borosilicate Erlenmeyer flask of $250 \mathrm{~mL}$ were used for the blank controls (one for each sampling time). In the test vessels, $100 \mathrm{mg}$ of test item was weighed into twelve separate $250 \mathrm{~mL}$ Erlenmeyer flasks (three replicate flasks for each sampling time, i.e. at $24,72,120$ and 168 hours). $50 \mathrm{~mL}$ of extraction fluid $\left(30^{\circ} \mathrm{C}\right.$ $\pm 1^{\circ} \mathrm{C}$ ) was added to each test item vessel and blank control vessel. After swirling the flasks to mix the test item and the medium, the $\mathrm{pH}$ of the solution of replicate $\mathrm{X}$ (additional test item vessel that was prepared was checked to assure that it is at $6.5 \pm 0.1$. Since the $\mathrm{pH}$ did not alter after addition of the test system to the test item, $\mathrm{pH}$ correction in the test vessels was not needed. The flasks were covered with a screw cap and placed into a temperature controlled orbital shaker $\left(30^{\circ} \mathrm{C} \pm 1^{\circ} \mathrm{C}\right)$ without agitation. The shaker was only used as a temperatureconditioned space. A set of one blank control vessel and three test vessels were removed for sampling after 24 hours, 72 hours 120 hours and 168 hours of elution, respectively.

\subsubsection{Chemical Analysis}

The determination of dissolved indium concentrations (In ion) in the blank control and test item vessels were carried out using an ICP-MS. The detection limit for indium was $10 \mu \mathrm{g} / \mathrm{L}$ and $1 \mu \mathrm{g} / \mathrm{L}$ in perspiration and gastric fluid respectively.

The analyses were performed in compliance with the ISO 17025 standard.

\subsection{Quality Assurance}

The bioelution testing was performed by ECTX-Consult. The laboratory generated a set of reports for each test item.

\section{Results}

\subsection{Example 1-Prediction of Skin-Sensitisation Endpoint}

\subsubsection{Assessment of Bioaccessibility of Indium Substances in Simulated Perspiration Fluids}

The results of In-ionrelease in perspiration fluid show comparably very low bioaccessibility for all tested substances, measured over 24 hours and over 168 hours (Table 3 ). For indium chloride and indium nitrate, no values could be reported as these substances precipitated out of the simulated perspiration fluid.

\subsubsection{Selection of Substances to Test in Vivo}

No experimental data were available in the literature on the skin sensitisation effect of In-substances. The observation from [37] that $\mathrm{InCl}_{3}$ is precipitated into $\operatorname{In}(\mathrm{OH})_{3}$ in neutral and alkali solutions was confirmed by the observed precipita- 
tion of $\mathrm{InCl}_{3}$ and $\mathrm{In}\left(\mathrm{NO}_{3}\right)_{3}$ at the start of the testing. Given this precipitation, the bioelution results of the $\operatorname{In}(\mathrm{OH})_{3}$ are considered valid for $\mathrm{InCl}_{3}$ and $\operatorname{In}\left(\mathrm{NO}_{3}\right)_{3}$. Considering further the similarly very low In-ion release from the other tested substances, $\operatorname{In}(\mathrm{OH})_{3}$, was selected for performing a skin sensitisation test.

The test was conducted according to OECD Guideline 406. Test animals are initially exposed to the test substance by intradermal injection and/or epidermal application (induction exposure). $\operatorname{In}(\mathrm{OH})_{3}$ was applied as a suspension at concentrations of $0.01 \%$ in $1 \%$ methylcellulose (intradermal injection) and $100 \%$ in $1 \%$ methylcellulose (epidermal application). Following a rest period of 10 to 14 days (induction period), during which an immune response may develop, the animals are exposed to a challenge dose. The extent and degree of skin reaction to the challenge exposure in the test animals are compared with that demonstrated by control animals that undergo sham treatment during induction and receive the challenge exposure [38]. The results of this test were negative (Table $4)$; no sensitisation potential was determined. As a consequence, $\operatorname{In}(\mathrm{OH})_{3}$ was not classified as a sensitiser.

Given the identical bio-elution data for the tested In-substances in perspiration fluid, and applying read-across, the absence of sensitisation potential concluded on $\operatorname{In}(\mathrm{OH})_{3}$ was also concluded for all tested indium compounds except $\mathrm{InCl}_{3} . \mathrm{InCl}_{3}$ is indeed a proven corrosive substance [39], which means that it cannot be tested for sensitisation purposes (EU REACH, 2007).

Table 3. Bioaccessibility of indium and indium compounds assessed from the recovery of indium after bioelution tests in perspiration fluids in accordance to the Eurometaux SOP, 2010 [31] and based on BS EN1811 [24].

\begin{tabular}{cccc}
\hline Test Substance & \multicolumn{2}{c}{$\begin{array}{c}\text { Bioaccessibility in simulated perspiration fluid } \\
\text { (loading 2g/L, } \mathrm{pH} \text { 6.5) }\end{array}$} & Reference \\
& 24 hours & 168 hours & \\
\hline $\mathrm{In}$ & $<10^{*}$ & $<10^{*}$ & {$[33]$} \\
$\mathrm{In}(\mathrm{OH})_{3}$ & $<10^{*}$ & $<10^{*}$ & {$[34]$} \\
$\mathrm{In}_{2} \mathrm{O}_{3}$ & $<10^{*}$ & $<10^{*}$ & {$[35]$} \\
$\mathrm{In}_{2} \mathrm{~S}_{3}$ & 24 & $<10^{*}$ & {$[36]$} \\
\hline
\end{tabular}

${ }^{*}<$ reporting limit of the analytical method is $10 \mu \mathrm{g} / \mathrm{L}$ indium.

Table 4. Skin sensitisation potential for $\operatorname{In}(\mathrm{OH})_{3}$ in an OECD 406 Magnusson-Kligman Study.

\begin{tabular}{|c|c|c|c|}
\hline Test Substance/Method & Results & Remarks & Reference \\
\hline \multicolumn{4}{|c|}{$\operatorname{In}(\mathrm{OH})_{3}$} \\
\hline Guinea Pig & \multirow{4}{*}{$\begin{array}{l}\text { No signs of contact } \\
\text { sensitisation were detected } \\
\text { after being exposed to the test } \\
\text { item during the experiments. }\end{array}$} & 1 (reliable without restriction) & \multirow{4}{*}[38]{} \\
\hline Intradermal and & & key study & \\
\hline & & Experimental result & \\
\hline $\begin{array}{l}\text { OECD Guideline } 406 \\
\text { (Skin Sensitisation) }\end{array}$ & & $\begin{array}{l}\text { Test material (EC name): } \\
\text { indium trihydroxide }\end{array}$ & \\
\hline
\end{tabular}




\subsection{Example 2-Prediction of Acute Oral Toxicity Endpoint}

\subsubsection{Assessment of Bioaccessibility of Indium Substances in Simulated Gastric Fluid}

The bioaccessibility of indium ions from indium substances was investigated by bioelution tests in the synthetic gastric fluid to provide an estimate of oral bioavailability and, consequently, of toxicity, after oral exposure. The gastric fluid is characterised by relative high chloride concentrations and low $\mathrm{pH}$. The bioelution data are summarised in Table 5 . Three different patterns of indium releasecan be identified in this gastric medium: complete release $( \pm 100 \%)$; limited release $(5 \%-10 \%)$ and no release $(<1 \%)$.

\subsubsection{Grouping of Indium Substances with Similar Bioelution Pattern in Gastric Medium}

Based on the bioaccessibility results after $2 \mathrm{~h}$ in gastric fluid, the following grouping is proposed:

- Highly soluble compounds: In-substances with high bioaccessibility $\left(\mathrm{InCl}_{3}\right.$, $\left.\operatorname{In}\left(\mathrm{NO}_{3}\right)_{3}\right)$

- Sparingly soluble substances: In-substances with moderate gastric bioaccessibility (In metal powder, $\operatorname{In}(\mathrm{OH})_{3}$ )

- Relatively insoluble compounds: In-substances characterised by very low gastric bioaccessibility $\left(\operatorname{In}_{2} \mathrm{O}_{3}, \mathrm{In}_{2} \mathrm{~S}_{3}\right)$

\subsubsection{Selection of Substances to Test for Acute Toxicity}

Acute oral toxicity data were available for $\mathrm{InCl}_{3}$ and In metal (powder). The results are summarised in Table 6 .

Of the available data, the result of the rat study on $\mathrm{InCl}_{3}[48]$ were considered inconclusive for classification (LD50 $=1983 \mathrm{mg} / \mathrm{kg} \mathrm{bw}$ ) due to the inclusion of $5 \%$ Tween 80 as a surfactant in the dose vehicle (distilled water). Tween 80 has been shown to inhibit the body's own natural detoxification process in the form of the permeability glycoprotein (P-gp) found on the apical/luminal membrane of intestinal cells [49]. The use of Tween 80 may therefore have caused an

Table 5. Bioaccessibility of indium and indium compounds assessed from the recovery of indium after bioelution tests on gastric fluids in accordance with the Eurometaux SOP, 2010 [31] and with ASTM D 5517-07 [28].

\begin{tabular}{cccc}
\hline Test Substance & $\begin{array}{c}\text { Bioaccessibility in Gastric fluid } \\
(2 \text { hours, loading } 0.2 \mathrm{~g} / \mathrm{L}) \\
\begin{array}{c}\text { Concentration of dissolved indium } \\
\text { released }(\mathrm{mg} / \mathrm{L})\end{array}\end{array}$ & $\begin{array}{c}\text { Bioaccessibility in Gastric fluid } \\
(2 \text { hours, loading } 0.2 \mathrm{~g} / \mathrm{L}) \\
\text { as \% In released of total } \\
\text { In-content }\end{array}$ & Reference \\
\hline $\mathrm{InCl}_{3}$ & $28.3 \pm 0.6$ & 102 & {$[40]$} \\
$\mathrm{In}\left(\mathrm{NO}_{3}\right)_{3}$ & $14.7 \pm 0.6$ & 99 & {$[41]$} \\
$\mathrm{In}$ & $18.7 \pm 6.8$ & 9.3 & {$[42]$} \\
$\mathrm{In}(\mathrm{OH})_{3}$ & $7.43 \pm 1.07$ & 5.1 & {$[43]$} \\
$\mathrm{In}_{2} \mathrm{O}_{3}$ & $0.243 \pm 0.032$ & 0.15 & {$[44]$} \\
$\mathrm{In}_{2} \mathrm{~S}_{3}$ & $0.640 \pm 0.010$ & 0.45 & {$[45]$} \\
\hline
\end{tabular}


Table 6. Overview of experimental studies on In-substances after oral administration.

\begin{tabular}{|c|c|c|c|}
\hline Test Substance/Method & Results & Remarks & Reference \\
\hline \multicolumn{4}{|c|}{ In } \\
\hline Rat (Crj: CD(SD) IGS rats (SPF)) & & 1 (reliable without restriction) & \\
\hline Male/female & LD50: > $2000 \mathrm{mg} / \mathrm{kg}$ bw & Key study & {$[46]$} \\
\hline Oral: gavage & (male/female) & Experimental result & [46] \\
\hline OECD Guideline 401 (Acute Oral Toxicity) & & Test material (EC name): indium & \\
\hline \multicolumn{4}{|c|}{$\mathrm{InCl}_{3}$} \\
\hline Rat (Wistar) female & & 1 (reliable without restriction) & \\
\hline Oral: gavage & LD50: > $2000 \mathrm{mg} / \mathrm{kg}$ bw & Key study & \\
\hline OECD Guideline 423 & (female) & Experimental result & [47] \\
\hline (Acute Oral Toxicity-Acute Toxic Class Method) & & Test material (EC name): indium trichloride & \\
\hline $\begin{array}{l}\text { Rat (Sprague-Dawley) male/female } \\
\text { Oral: gavage } \\
\text { OECD Guideline } 401 \\
\text { (Acute Oral toxicity) }\end{array}$ & $\begin{array}{c}\text { LD50: ca. } 1983 \mathrm{mg} / \mathrm{kg} \text { bw } \\
\text { (male/female) } \\
\text { (confidence interval values: LD84 } \\
2283 \mathrm{mg} / \mathrm{kg} \text { (male) and LD16 } \\
1741 \mathrm{mg} / \mathrm{kg} \text { (female) }\end{array}$ & $\begin{array}{l}3 \text { (unreliable). See below Test material } \\
\text { (EC name): indium trichloride }\end{array}$ & [48] \\
\hline
\end{tabular}

overestimation of toxicity making the study unreliable for classification purposes. Therefore, the study was repeated under the standard conditions of the more recent Acute Oral Toxicity-Acute Toxic Class Method (OECD Guideline 423). The LD50 of this further recent study was clearly $>2000 \mathrm{mg} / \mathrm{kg}$ bw [47].

The result of the study with rat on In metal powder [46] was considered conclusive. For the other indium compounds under consideration in the consortium, no experimental data were available, and no further animal testing was conducted.

\subsubsection{Read-Across to Get Estimation of Acute Toxicity of Indium Substances (Table 7)}

The grouping of indiumsubstances with similar bioaccessibility pattern/solubility in gastric medium (see section 3.2.3., Table 5) was used as the basis for the read-across of acute oral toxicity data within and/or between groups for defining the acute oral toxicity of the different indium compounds:

- the toxicity data on $\mathrm{InCl}_{3}$ were read across to the other highly soluble indium substance $\left(\operatorname{In}\left(\mathrm{NO}_{3}\right)_{3}\right)$

- the toxicity data on In metal were read across to the other slightly soluble $\left(\mathrm{In}(\mathrm{OH})_{3}\right)$ and as worst case to the insoluble indium compounds $\left(\operatorname{In}_{2} \mathrm{O}_{3}\right.$, $\mathrm{In}_{2} \mathrm{~S}_{3}$ ) for which the toxicity potential is considered even lower because of lower solubility.

\section{Discussion}

These studies suggest that bioelution can be used as a screening tool when having to characterise a metal-containing material for toxicity and assessing their bioavailability. The results of oral bioelution tests, based on the ASTM D 5517-07 method [25] were used to characterise the hazard of six indium substances for acute oral toxicity. Similarly, the results from testing in synthetic sweat based on BS EN1811 protocol [24] were used to complete the knowledge 
Table 7. Summary of estimated toxicity from read-across.

\begin{tabular}{|c|c|c|c|}
\hline Substance & Solubility Group & $\begin{array}{l}\text { Read across from } \\
\text { substance }\end{array}$ & Estimated Toxicity \\
\hline $\operatorname{In}\left(\mathrm{NO}_{3}\right)_{3}$ & Highly soluble & $\mathrm{InCl}_{3}$ & $>2000 \mathrm{mg} / \mathrm{kg}$ bw (female rat) \\
\hline $\operatorname{In}(\mathrm{OH})_{3}$ & Slightly soluble & Indium metal powder & $>2000 \mathrm{mg} / \mathrm{kg}$ bw (male/female rat) \\
\hline $\mathrm{In}_{2} \mathrm{O}_{3}$ & Insoluble & $\begin{array}{l}\text { Indium metal powder in } \\
\text { conservative approach }\end{array}$ & $\begin{array}{l}\qquad 2000 \mathrm{mg} / \mathrm{kg} \mathrm{bw} \\
\text { Less toxic than In metal powder because } \\
\text { of (s)lower solubility }\end{array}$ \\
\hline $\mathrm{In}_{2} \mathrm{~S}_{3}$ & Insoluble & $\begin{array}{l}\text { Indium metal powder in } \\
\text { conservative approach }\end{array}$ & $\begin{array}{l}\quad>2000 \mathrm{mg} / \mathrm{kg} \text { bw } \\
\text { Less toxic than } \operatorname{In}(\mathrm{OH})_{3} \\
\text { because of }(\mathrm{s}) \text { lower solubility }\end{array}$ \\
\hline
\end{tabular}

on skin-sensitisation for these compounds.

For acute oral toxicity, the six indium substances were grouped by similar bioelution pattern depending on the releases measured in physiological fluid relevant for the endpoints under study (i.e. gastric juice). Two groups were identified: highly soluble compounds $\left(\mathrm{In}\left(\mathrm{NO}_{3}\right)_{3}\right.$ and $\left.\mathrm{InCl}_{3}\right)$ and slightly soluble and insoluble compounds (In metal, $\operatorname{In}(\mathrm{OH})_{3}, \operatorname{In}_{2} \mathrm{O}_{3}$ and $\operatorname{In}_{2} \mathrm{~S}_{3}$ ). Based on these groups, appropriate indium compounds were selected for in vivo testing, e.g. $\mathrm{InCl}_{3}$ for acute toxicity for the highly soluble compounds. Tested results on this compound were read-across to $\operatorname{In}\left(\mathrm{NO}_{3}\right)_{3}$ belonging to the same group. For the less soluble compounds, indium metal was selected as source substance and the available toxicity data were used for read-across.

For skin sensitisation, the results in the sweat test allowed to support read across from $\operatorname{In}(\mathrm{OH})_{3}$ as source substance.

The two cases presented above demonstrate that the bioelution approach to predict the hazard and grouping of indium compounds could be used to reduce animal testing, for these six indium compounds. The results can be used as part of a submission to regulatory authorities to respond to data requirements, but it is important to acknowledge that such data should be complemented with other data in a weight-of-evidence approach (e.g. physicochemical data).

This approach is similar to the study by Henderson et al. [3] who reported the outcome of the bioaccessibility testing of nickel substances in gastric and intestinal fluids and the development of a read-across paradigm for oral systemic toxicity based on the correlation between bioaccessibility data and in vivo acute oral toxicity data. Like indium, the acute oral toxicity of nickel substances could be grouped according to the extent of bioaccessibility.

The approach described above is however facing some limitations. There is still no standardised protocol, although it is under development. Because of this, the bioelution method should still be used in a comparative way, comparing ion releases from the material of interest to releases from a reference substance(s) or materials(s) for which toxicity data are already available. Also, some routes of exposure have been more carefully examined than others e.g. oral route for systemic effects. However, care has to be taken when evaluating other routes of exposure (e.g. inhalation) or local effects, where the solubilisation of a substance or 
material may only be one factor in predicting toxicity, whereas other factors may play an equal or even a more significant role.

Overall, the study leads to the prospect that the database of indium and indium compounds can be further developed through a programme of minimal animal testing and comparative bioelution studies. The application of a read across assessment from a reference indium substance to relatively data-poor indium substances can be used to determine the potential impact on hazard classification for repeat dose endpoints, e.g. genotoxicity and reprotoxicity.

\section{Acknowledgements}

This study was funded through the Indium REACH Consortium.

\section{References}

[1] Russell, W.M.S. and Burch, R.L. (1959) The Principles of Humane Experimental Technique. Methuen, London.

[2] Hillwalker, W.E. and Anderson, K.A. (2014) Bioaccessibility of Metals in Alloys: Evaluation of Three Surrogate Biofluids. Environmental Pollution, 185, 52-58. https://doi.org/10.1016/j.envpol.2013.10.006

[3] Henderson, R.G., Durando, J., Oller, A.R., Merkel, D.J., Marone, P.A. and Bates, H.K. (2012) Acute Oral Toxicity of Nickel Compounds. Regulatory Toxicology and Pharmacology, 62, 425-432. https://doi.org/10.1016/j.yrtph.2012.02.002

[4] Henderson, R.G., Verougstraete, V., Anderson, K., Arbildua, J.J., Brock, T.O., Brouwers, T., Cappellini, D., Delbeke, K., Herting, G., Hixon, G., Odnevall Wallinder, I., Rodriguez, P.H., Van Assche, F., Wilrich, P. and Oller, A.R. (2014) Inter-Laboratory Validation of Bioaccessibility Testing for Metals. Regulatory Toxicology and Pharmacology, 70, 170-181. https://doi.org/10.1016/j.yrtph.2014.06.021

[5] Stopford, W., Turner, J., Cappellini, D. and Brock, T. (2003) Bioaccessibility Testing of Cobalt Compounds. Journal of Environmental Monitoring, 5, 675-680. https://doi.org/10.1039/b302257a

[6] Herting, G., Odnevall Wallinder, I. and Leygraf, C. (2008) Metal Release Rate from AISI 316L Stainless Steel and Pure Fe, Cr and Ni into a Synthetic Biological Medium-a Comparison. Journal of Environmental Monitoring, 10, 1092-1098. https://doi.org/10.1039/b805075a

[7] Hedberg, Y., Midander, K. and Odnevall Wallinder, I. (2010) Particles, Sweat, and Tears: A Comparative Study on Bioaccessibility of Ferrochromium Alloy and Stainlesssteel Particles, the Pure Metals and Their Metal Oxides, in Simulated Skin and Eye Contact. Integrated Environmental Assessment and Management, 6, 456-468. https://doi.org/10.1002/ieam.66

[8] Mazinanian, N., Hedberg, Y. and Odnevall Wallinder, I. (2013) Nickel Release and Surface Characteristics of Fine Powders of Nickel Metal and Nickel Oxide in Media of Relevance for Inhalation and Dermal Contact. Regulatory Toxicology and Pharmacology, 65, 135-146. https://doi.org/10.1016/j.yrtph.2012.10.014

[9] Oller, A.R., Cappellini, D., Henderson, R.G. and Bates, H.K. (2009) Comparison of Nickel Release in Solutions Used for the Identification of Water-Soluble Nickel Exposures and in Synthetic Lung Fluids. Journal of Environmental Monitoring, 11, 823-829. https://doi.org/10.1039/b820926j

[10] Hamel, S.C., Buckley, B. and Lioy, P.J. (1998) Bioaccessibility of Metals in Soils for 
Different Liquid to Solid Ratios in Synthetic Gastric Fluid. Environmental Science \& Technology, 32, 358-362. https://doi.org/10.1021/es9701422

[11] Vasiluk, L., Dutton, M.D. and Hale, B. (2011) In Vitro Estimates of Bioaccessible Nickel in Field-Contaminated Soils, and Comparison with in Vivo Measurement of Bioavailability and Identification of Mineralogy. Science of the Total Environment, 409, 2700-2706. https://doi.org/10.1016/j.scitotenv.2011.03.035

[12] Drexler, J.W. and Brattin, W.J. (2007) An in Vitro Procedure for Estimation of Lead Relative Bioavailability: With Validation. Human and Ecological Risk Assessment, 13, 383-401. https://doi.org/10.1080/10807030701226350

[13] Wragg, J., Cave, M., Basta, N., Brandon, E., Casteel, S., Denys, S., Gron, C., Oomen, A., Reimer, K., Tack, K. and Van de Wiele, T. (2011) An Inter-Laboratory Trial of the Unified BARGE Bioaccessibility Method for Arsenic, Cadmium and Lead in Soil. Science of the Total Environment, 409, 4016-4030.

https://doi.org/10.1016/j.scitotenv.2011.05.019

[14] Ellickson, K.M., Meeker, R.J., Gallo, M.A., Buckley, B.T. and Lioy, P.J. (2001) Oral Bioavailability of Lead and Arsenic from a NIST Standard Reference Soil Material. Archives of Environmental Contamination and Toxicology, 40, 128-135. https://doi.org/10.1007/s002440010155

[15] Gray, J.E., Plumlee, G.S., Morman, S.A., Higueras, P.L., Crock, J.G., Lowers, H.A. and Witten, M.L. (2010) In Vitro Studies Evaluating Leaching of Mercury from Mine Waste Calcine Using Simulated Human Body Fluids. Environmental Science \& Technology, 44, 4782-4788. https://doi.org/10.1021/es1001133

[16] Twining, J., McGlinn, P., Loi, E., Smith, K. and Gieré, R. (2005) Risk Ranking of Bioaccessible Metals from Fly Ash Dissolved in Simulated Lung and Gut Fluids. Environmental Science \& Technology, 39, 7749-7756. https://doi.org/10.1021/es0502369

[17] Hedberg, Y., Hedberg, J. and Odnevall Wallinder, I. (2012) Particle Characteristics and Metal Release from Natural Rutile $\left(\mathrm{TiO}_{2}\right)$ and Zircon Particles in Synthetic Body Fluids. Journal of Biomaterials and Nanobiotechnology, 3, 37-49. https://doi.org/10.4236/jbnb.2012.31006

[18] Hedberg, Y., Wang, X., Hedberg, J., Lundin, M., Blomberg, E. and Odnevall Wallinder, I. (2013) Surface-Protein Interactions on Different Stainless-Steel Grades: Effects of Protein Adsorption, Surface Changes and Metal Release. Journal of Materials Science: Materials in Medicine, 24, 1015-1033.

https://doi.org/10.1007/s10856-013-4859-8

[19] Hedberg, Y., Mazinanian, N. and Odnevall Wallinder, I. (2013b) Metal Release from Stainless Steel Powders and Massive Sheets-Comparison and Implication for Risk Assessment of Alloys. Environmental Science: Processes \& Impacts, 15, 381-392. https://doi.org/10.1039/C2EM30818E

[20] Guney, M. and Zagury, G.J. (2014) Bioaccessibility of As, Cd, Cu, Ni, Pb, and Sb in Toys and Low-Cost Jewelry. Environmental Science \& Technology, 48, 1238-1246. https://doi.org/10.1021/es4036122

[21] Diamond, G.L., Bradham, K.D., Brattin, W.J., Burgess, M., Griffin, S., Hawkins, C.A., Juhasz, A.L., Klotzbach, J.M., Nelson, C., Lowney, Y.W., Scheckel, K.G. and Thomas, D.J. (2016) Predicting Oral Relative Bioavailability of Arsenic in Soil from in Vitro Bioaccessibility. Journal of Toxicology and Environmental Health, 79, 165-173. https://doi.org/10.1080/15287394.2015.1134038

[22] Herting, G., Jiang, T., Sjöstedt, C. and Odnevall Wallinder, I. (2014) Release of Si from Silicon Metalloids, a FeSi Alloy and a Silicate Mineral in Simulated Biological 
Media. PLoS ONE, 9, e107668. https://doi.org/10.1371/journal.pone.0107668

[23] Stockmann-Juvala, H., Hedberg, Y., Dhinsa, N.K., Griffiths, D.R., Brooks, P.N., Zitting, A., Odnevall Wallinder, I. and Santonen, T. (2013) Inhalation Toxicity of 316L Stainless Steel Powder in Relation to Bioaccessibility. Human \& Experimental Toxicology, 32, 1137-1154. https://doi.org/10.1177/0960327112472354

[24] BSEN1811 (BS (British Standard) EN 1811 (2011) Reference Test Method for Release of Nickel from All Post Assemblies Which Are Inserted into Pierced Parts of the Human Body and Articles Intended to Come into Direct and Prolonged Contact with the Skin.

[25] U.S. EPA (2004) Extractability of Pb from Soil (Gastric Fluid).

[26] BS (British Standard) EN 71-3 (2013) Safety of Toys. Migration of Certain Elements.

[27] ASTM F963-11 (2011) Standard Consumer Safety Speciation for Toy Safety. American Society for Testing and Materials, Philadelphia.

[28] ASTM D5517-07 (2007) Standard Test Method for Determining Extractability of Metals from Art Materials, D5517-94. American Society for Testing and Materials, Philadelphia.

[29] BARGE (Bioaccessibility Research Group of Europe). In Vivo (Swine) Validation of Soil Contaminants: Arsenic, Cadmium and Lead via the Gastrointestinal Tract.

[30] Oomen, A.G., Rompelberg, C.J.M., Brandon, E.F.A., van de Kamp, E., Duits, M.R., Versantvoort, C.H.M., van Engelen, J.G.M. and Sips, A.J.A.M. (2005) Consumer Product in Vitro Digestion Model: Bioaccessibility of Contaminants from Toys and Application in Risk Assessment. Regulatory Toxicology and Pharmacology, 44, 161-171.

[31] Eurometaux (2010) The Standard Operating Procedure for the Bio-Accessibility Testing Programme of Eurometaux, November 10.

[32] Tomlin, J., Brown, N., Ellis, A., Carlsson, A., Bogentoft, C. and Read, N.W. (1993) The Effect of Liquid Fibre on Gastric Emptying in the Rat and Humans and the Distribution of Small Intestinal Contents in the Rat. Gut, 34, 1177-1181. https://doi.org/10.1136/gut.34.9.1177

[33] Brouwers, T. (2014) 168 Hours Bio-Elution Test on Indium at a 2g/L Loading in a Simulated Perspiration Fluid.

[34] Brouwers, T. (2014) 168 Hours Bio-Elution Test on Indium(III) Hydroxide at a 2g/L Loading in a Simulated Perspiration Fluid.

[35] Brouwers, T. (2014) 168 Hours Bio-Elution Test on Indium(III) Oxide at a 2g/L Loading in a Simulated Perspiration Fluid.

[36] Brouwers, T. (2014) 168 Hours Bio-Elution Test on Indium(III) Sulfide at a 2g/L Loading in a Simulated Perspiration Fluid.

[37] Wang, L., Pérez-Magueda, L.A. and Matijevic, E. (1998) Rapid Preparation of Uniform Colloidal Indium Hydroxide by the Controlled Double-Jet Precipitation. Colloid \& Polymer Science, 276, 847-850. https://doi.org/10.1007/s003960050320

[38] Török-Bathó, M. (2012) Indium Trihydroxide $\left(\operatorname{In}(\mathrm{OH})_{3}\right)$ : Skin Sensitisation Study in the Guinea Pig Using the Magnusson and Kligman Method.

[39] Kiss, I. (2012) Indium Trichloride $\left(\mathrm{InCl}_{3}\right)$ : Skin Corrosivity in Vitro Test in the EPISKIN Model.

[40] Brouwers, T. (2014) 2 Hours Bio-Elution Test on Indium(III) Chloride at a 200 $\mathrm{mg} / \mathrm{L}$ Loading in a Simulated Gastric Fluid. 
[41] Brouwers, T. (2014) 2 Hours Bio-Elution Test on Indium(III) Nitrate at a $200 \mathrm{mg} / \mathrm{L}$ Loading in a Simulated Gastric Fluid.

[42] Brouwers, T. (2014) 2 Hours Bio-Elution Test on Indium at a $200 \mathrm{mg} / \mathrm{L}$ Loading in a Simulated Gastric Fluid.

[43] Brouwers, T. (2014) 2 Hours Bio-Elution Test on Indium(III) Hydroxide at a 200 $\mathrm{mg} / \mathrm{L}$ Loading in a Simulated Gastric Fluid.

[44] Brouwers, T. (2014) 2 Hours Bio-Elution Test on Indium(III) Oxide at a $200 \mathrm{mg} / \mathrm{L}$ Loading in a Simulated Gastric Fluid.

[45] Brouwers, T. (2014) 2 Hours Bio-Elution Test on Indium(III) Sulfide at a $200 \mathrm{mg} / \mathrm{L}$ Loading in a Simulated Gastric Fluid.

[46] Asakura, K., Satoh, H., Chiba, M., Okamoto, M., Serizawa, K., Nakano, M. and Omae, K. (2008) Oral Toxicity of Indium in Rats: Single and 28-Day Repeated Administration Studies. Journal of Occupational Health, 50, 471-479. https://doi.org/10.1539/joh.L8070

[47] Kiss, I. (2012b) Indium Trichloride ( $\mathrm{InCl} 3$ ): Acute Oral Toxicity Study in Rats.

[48] Szakmary, E., Mandy, M., Kovacs, M., Tatrai, E. and Ungvary, G. (2001) Acute Oral Toxicity and Dermal Irritation Test of Indium Chloride. Central European Journal of Occupational and Environmental Medicine, 7, 60-65.

[49] Zhang, H., Yao, M., Morrison, R.A. and Chong, S. (2003) Commonly Used Surfactant, Tween 80, Improves Absorption of P-Glycoprotein Substrate, Digoxin, in Rats. Archives of Pharmacal Research, 26, 768-772. https://doi.org/10.1007/BF02976689 